\title{
DESAIN PENGEMBANGAN MODEL PRAKTIKUM RANGKAIAN LISTRIK BERBASIS MASALAH TERHADAP KETERAMPILAN SCIENTIFIC INQUIRYDAN KOGNISI MAHASISWA
}

\author{
Sehat Simatupang, Togi Tampubolon dan Erniwati Halawa \\ Jurusan Fisika FMIPA Universitas Negeri Medan \\ simatorop15@gmail.com
}

\begin{abstract}
ABSTRAK
Desain penelitian bertujuan untuk mengembangkan model Praktikum Rangkaian Listrik berbasis masalah terhadap keterampilan scientific inquiry dan kognisi mahasiswa dengan menggunakan desain Research and Development. Analisis kebutuhan dilakukan melalui studi pustaka dan lapangan. Model yang dikembangkan diimplementasikan pada matakuliah Praktikum Rangkaian Listrik pada topik Rangkaian DC dan AC di Universitas Negeri Medan. Metode yang digunakan dalam penelitian ujicoba terbatas pra-eksperimental. Metode pada ujicoba skala luas kuasieksperimen di Universitas Negeri Medan. Draft model pembelajaran Praktikum Rangkaian Listrik berbasis masalah yang telah disempurnakan berdasarkan hasil ujicoba skala luas, selanjutnya dilakukan diseminasi secara laus.
\end{abstract}

Kata Kunci : Model Pembelajaran Berbasis Masalah, Keterampilan Scientific Inquiry dan Kognisi

\section{PENDAHULUAN}

Fisika memiliki dimensi produk dan proses (Rutherford \& Ahlgren, 1990; Wenning, 2011). Dilihat dari sisi produk, Fisika merupakan ilmu pengetahuan tentang fenomena alam, berupa kumpulan fakta, konsep, prinsip, teori dan hukum serta proses yang sistematis yang dapat diuji kebenarannya. Dilihat dari sisi proses, fisika memerlukan keterampilan-keterampilan dasar yang biasa digunakan para ilmuwan dalam bekerja secara ilmiah. Keterampilan - keterampilan diperlukan untuk menentukan variabel-variabel yang diteliti dengan mengidentifikasi masalah, melakukan eksperimen ilmiah untuk mengumpulkan data, menerapkan metode numerik dan statistik untuk mendukung kesimpulan, merumuskan hipotesis dan menggunakan teknologi yang tersedia. Kegiatan-kegiatan tersebut merupakan bagian dari keterampilan scientific inquiry (Wenning, 2011).

Berdasarkan

analisis kurikulum, keterampilan scientific inquiry merupakan salah satu acuan pembelajaran yang harus dijadikan dosen dalam melaksanakan pembelajaran.

Dosen sudah seharusnya menumbuhkan potensi keterampilan scientific inquiry 
dalam diri mahasiswa dan mengembangkannya sesuai dengan taraf pemikiran mahasiswa. Keterampilan scientific inquiry itu akan menjadi roda penggerak penemuan dan pengembangan fakta dan konsep serta penumbuhan dan pengembangan sikap dan nilai sehingga menciptakan cara belajar mahasiswa yang aktif sehingga hasil belajar mereka akan lebih meningkat. Keterampilan scientific inquiry dapat dikembangkan dengan melalui praktikum (Wenning, 2011 dan Woolnough \& Allsop dalam Rustaman, 2003).

Standar Pendidikan Sains Nasional Amerika (NRC, 1996) menyarankan bahwa dalam perkuliahan penyiapan guru sains, pengembangan profesionalnya harus memberikan pembekalan kemampuan pengambilan keputusan, penguasaan teori, bernalar dan kerja praktik atau praktikum. Untuk calon guru fisika, praktikum bertujuan untuk membangun kompetensi calon guru dalam mengembangkan konsepkonsep fisika dengan memanfaatkan teknologi dan seni dan mampu menggunakan peralatan fisika dalam pengembangan konsepkonsep fisika (Depdiknas, 2004).

Berdasarkan hasil studi pendahuluan terhadap hasil belajar Praktikum Rangkaian Listrik di Jurusan Pendidikan Fisika ternyata baru mampu meningkatkan pengembangan keterampilan dasar melaksanakan eksperimen, belum mampu meningkatan keterampilan scientific inquiry. Hal ini yerjadi karena selama ini praktikum fisika khususnya Rangkaian Listrik masih bersifat verifikatif.
Ünal \& Özdemir (2013) dan Heller \& Heller (1999) mengingatkan bahwa langkah kerja dalam laboratorium bersifat verifikatif kurang memberi peluang memproses informasi secara mendalam dan perhatian utama mahasiswa hanyalah penyelesaian tugas praktikum. Lebih lanjut Heller \& Heller menyatakan Jurusan Fisika di berbagai belahan dunia telah menginvestasikan sejumlah besar uang untuk memberikan pengalaman praktikum untuk mahasiswanya, akan tetapi jarang mengevaluasi apa yang seharusnya dicapai dalam praktikum.

Salah satu model pembelajaran yang memberikan peluang bagi mahasiswa untuk memiliki pengalaman menemukan suatu konsep dan mengembangkan keterampilan scientific inquiry adalah dengan model pembelajaran berbasis masalah. Pembelajaran ini merupakan salah satu model yang membentuk mahasiswa melakukan pemecahan masalah secara kreatif, aktif dan menghargai keragaman yang timbul selama proses pemecahan masalah dengan kata lain model pembelajaran berbasis masalah merupakan model pembelajaran yang menggunakan masalah dunia nyata sebagai suatu konteks bagi mahasiswa untuk belajar tentang keterampilan pemecahan masalah, keterampilan scientific inquiry untuk memperoleh pengetahuan dan konsep essensial.

\section{METODE PENELITIAN}

Penelitian ini menggunakan metode $\mathrm{R}$ and $\mathrm{D}$ melalui langkahlangkah 4-D, yaitu: pendefinisian (define), pendesainan (design), 
pengembangan (develop) dan diseminasi (disseminate) dengan penyesuaian (Thiagarajan, et al., 1974).

Tahap pendefinisian dilakukan melalui studi literatur dan studi lapangan. Tahap pendesainan dilakukan dengan merancang draft awal model yang dikembangkan dan perangkat pembelajaran untuk mendukung model pembelajaran Fisika Umum berbasis masalah pada materi Rangkaian DC dan AC, berupa (1) Pedoman pengelolaan pembelajaran; (2) Perancangan silabus berbasis masalah; Perancangan LKM; (4) Perangkat tes, berupa: tes keterampilan scientific inquiry berbentuk uraian berjumlah 15 item, tes kognisi berbentuk pilihan ganda berjumlah 32 item dan lembar observasi, angket, dan pedoman observasi.

Tahap pengembangan dilakukan dengan memvalidasi instrumen dan perangkat pembelajaran kepada ahli, melakukan uji coba terbatas, ujicoba skala luas dan diseminasi model yang dikembangkan. Ujicoba terbatas dan ujicoba skala luas dilakukan di Universitas Negeri Medan.

Data yang diperoleh pada penelitian ini terdiri atas data kualitatif dan kuantitatif. Data kualitatif berupa: 1) karakteristik model pembelajaran berbasis masalah; 2) efektifitas model pembelajaran yang dikembangkan terhadap keterampilan scientific inquiry dan kognisi mahasiswa; 3) kelebihan model pembelajaran berbasis masalah yang dikembangkan; dan 3) tanggapan dosen dan mahasiswa terhadap model pembelajaran yang dikembangkan.

Data penelitian ini terdiri dari data kuantitatif dan kualitatif. Data kuantitatif berupa skor tes keterampilan scientific inquiry dan kognisi mahasiswa. Data kualitatif dianalisis secara deskriptif interpretatif. Data kuantitatif dianalisis dengan menggunakan statistik inferensial.

\section{HASIL DAN PEMBAHASAN}

Studi pendahuluan di Universitas Negeri Medan. Studi pendahuluan dimaksudkan untuk mendapatkan gambaran tentang apa yang diperlukan mahasiwa sebagai calon guru fisika dan dapat dipenuhi melalui perkuliahan Praktikum Rangkaian Listrik, bagaimanakah kondisi perkuliahan Praktikum Rangkaian Listrik yang selama ini telah dilakukan, fasilitas belajar yang tersedia, serta latar belakang mahasiswa ditinjau dari keterampilan scientific inquiry dan kognisi.

Studi pendahuluan dilakukan dengan studi literatur dan studi lapangan. Melalui studi literatur dilakukan analisis terhadap kompetensi seorang guru fisika serta peran perkuliahan Praktikum Rangkaian Listrik, keterampilan scientific inquiry dan kognisi berpikir kritis, teori-teori dan temuan-temuan penelitian. Studi lapangan dilakukan melalui observasi, wawancara, dan tes. Analisis keterampilan scientific inquiry dan kognisi mahasiswa terhadap perkuliahan Praktikum Rangkaian Listrik digali melalui tes. Analisis kesulitan dan tanggapan mahasiswa terhadap perkuliahan 
Praktikum Rangkaian Listrik digali melalui wawancara.

Berdasarkan hasil pengamatan di lapangan, Praktikum Rangkaian Listrik bersifat verifikasi. Mahasiswa melakukan praktikum sesuai langkah-langkah yang sudah tertulis di buku penuntun praktikum. Dengan mengikuti langkah-langkah sesuai dengan buku penuntun praktikum, mahasiswa kurang dalam hal berpikir kritis dan kreatif serta kurang dilatih scientific inquiry nya.

Selama ini juga dalam perkuliahan Praktikum Rangkaian Listrik, mahasiswa tidak dihadapkan pada masalah yang berkaitan dalam kehidupan seharihari, padahal materi Praktikum Rangkaian Listrik sangat erat berkaitan dengan kehidupan seharihari terutama pada sub materi Rangkaian DC dan AC. Saat menghadapi masalah yang berkaitan dengan kehidupan seharihari sesuai dengan sub materi ini, mahasiswa tentu tidak dapat mencari solusinya.

Berdasarkan hasil wawancara, dosen belum pernah mengembangkan model pembelajaran berbasis masalah yang dapat meningkatkan keterampilan scientific inquiry secara khusus. Walaupun belum pernah mengembangkan model pembelajaran berbasis masalah yang dapat meningkatkan keterampilan scientific inquiry, dosen memandang perlu untuk mengembangkan model pembelajaran berbasis masalah yang dapat meningkatkan keterampilan scientific inquiry dan kognisi secara khusus.
Studi pendahuluan juga dilakukan terhadap sumber belajar dan fasilitas yang tersedia. Berkaitan dengan sumber belajar, umumnya mahasiswa menggunakan buku ajar (diktat) yang dibuat oleh tim dosen Praktikum Rangkaian Listrik sebagai sumber buku utama. Menurut mereka, buku ini merupakan buku pegangan dosen yang digunakan dalam perkuliahan, materinya diramu dari beberapa sumber. Selain buku ajar, mahasiswa juga memanfaatkan buku-buku teks yang tersedia di perpustakaan lembaga.

Berdasarkan

analisis kebutuhan mahasiswa dan kondisi perkuliahan Praktikum Rangkaian Listrik, maka salah satu tujuan yang hendak dicapai dalam perkuliahan ini adalah meningkatkan keterampilan scientific inquiry dan kognisi mahasiswa.

$$
\text { Indikator keterampilan }
$$
scientific inquiry yang akan dikembangkan dalam penelitian ini adalah mengidentifikasi masalah, melakukan eksperimen ilmiah untuk mengumpulkan data, menerapkan metode numerik dan statistik untuk mencapai dan mendukung kesimpulan, merumuskan hipotesis dan menggunakan teknologi yang tersedia (Wenning, 2011).

Indikator dalam ranah kognisi adalah mengingat, memahami, mengaplikasikan, menganalisis, mengevaluasi dan mencipta (Anderson \& Krathwol, 2010).

\section{KESIMPULAN DAN SARAN}

Kesimpulan yang didapat berdasarkan hasil penelitian yang 
telah dilakukan adalah sebagai berikut:

1. Telah dirancang model pembelajaran Praktikum Rangkaian Listrik berbasis masalah untuk meningkatkan keterampilan scientific inquiry dan kognisi mahasiswa.

2. Indikator keterampilan scientific inquiry yang dikembangkan adalah mengidentifikasi masalah, melakukan eksperimen ilmiah untuk mengumpulkan data, menerapkan metode numerik dan statistik untuk mencapai dan mendukung kesimpulan, merumuskan hipotesis dan menggunakan teknologi yang tersedia.

3. Indikator kognisi yang dikembangkan adalah mengingat, memahami, mengaplikasikan, menganalisis, mengevaluasi dan mencipta.

\section{DAFTAR PUSTAKA}

Anderson, L.W. \& Krathwol, D.R. (eds). (2001). A Taxonomy for Learning Teaching and Assessing. A Revision of Bloom's Taxonomy of Educational Objectives. New York: Addison Wesley Longman, Inc.

Depdiknas. (2004). Standar Kompetensi Guru Pemula Program Studi Pendidikan Fisika Jenjang S1. Jakarta: Direktur Jenderal Perguruan Tinggi.

Heller, K., \& Heller, P. (1999). Problem-Solving Labs. Introductory Physics I Mechanics. Cooperative Group problem-solving in physics.

National Research Council. (1996). National Science Education
Standards. Washington: DC, National Academy Press.

Rustaman, N.Y. (2003). Perencanaan dan Penilaian Praktikum di Perguruan Tinggi. Hand Out Program Applied Approach bagi Dosen Baru Universitas Pendidikan Indonesia. Bandung, 13-25 Januari 2003.

Rutherford, F. J. \& Ahlgren, A. (1990). Science for All Americans. New York: Oxford University Press.

Thiagarajan, S., Semmel, D. S. \& Semmel, M. (1974). Instructional Development for Training Teachers of Exceptional Children. Source Book. Bloominton: Center for Innovation on Teaching the Handicapped.

Ünal, C. \& Özdemir, Ö. F. (2013). A physics laboratory course designed using problem-based learning for prospective physics teachers. European Journal of Science and Mathematics Education 1(1) 29-33.

Wenning, C. J. 2011. Experimental inquiry in introductory physics courses. Journal of Physics Teacher Education Online. 6(2) 1-8. 